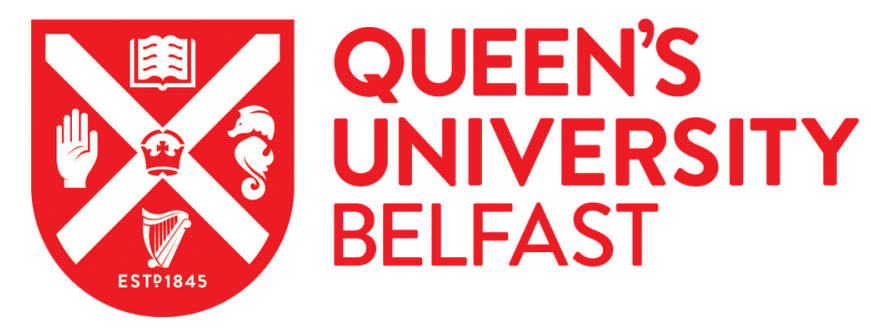

\title{
Gamma-ray log correlation and interpretation of Fitton and Casey's Stratigraphy with offshore borehole 99/16-1
}

Ruffell, A., \& Wach, G. D. (2019). Gamma-ray log correlation and interpretation of Fitton and Casey's Stratigraphy with offshore borehole 99/16-1. Proceedings of the Geologists' Association.

https://doi.org/10.1016/j.pgeola.2019.07.003

\section{Published in:}

Proceedings of the Geologists' Association

\section{Document Version:}

Peer reviewed version

Queen's University Belfast - Research Portal:

Link to publication record in Queen's University Belfast Research Portal

\section{Publisher rights}

Copyright 2019 Elsevier

This manuscript is distributed under a Creative Commons Attribution-NonCommercial-NoDerivs License

(https://creativecommons.org/licenses/by-nc-nd/4.0/), which permits distribution and reproduction for non-commercial purposes, provided the author and source are cited.

\section{General rights}

Copyright for the publications made accessible via the Queen's University Belfast Research Portal is retained by the author(s) and / or other copyright owners and it is a condition of accessing these publications that users recognise and abide by the legal requirements associated with these rights.

Take down policy

The Research Portal is Queen's institutional repository that provides access to Queen's research output. Every effort has been made to ensure that content in the Research Portal does not infringe any person's rights, or applicable UK laws. If you discover content in the Research Portal that you believe breaches copyright or violates any law, please contact openaccess@qub.ac.uk. 


\section{Gamma-ray Log Correlation and Interpretation of Fitton and Casey's Stratigraphy With Offshore Borehole 99/16-1}

\section{A.H. Ruffell ${ }^{1} \&$ G.D. Wach ${ }^{2}$}

RUFFELL, A.H. \& WACH, G.D. 20XX. Gamma-ray log correlation and interpretation of Fitton and Casey's Stratigraphy with offshore borehole 99/16-1 (Channel Basin). Proceedings of the Geologists' Association, XXX, The Chale Bay type section of the Lower Greensand Group (LGS) Atherfield Clay, Ferruginous Sands and Sandrock formations is characterised by members, bounded by hiatuses, formerly recognised (if not named as such) by Fitton (1847) as his 'groups' and Casey (1961) in defining ammonite zone and sub-zone boundaries. Subsequent work has shown that some of the formations of the LGS are recognised elsewhere on the Isle of Wight, in southern England and in northern France. Likewise, some members of the Atherfield Clay and Ferruginous Sands formations can be recognised beyond the Chale Bay type section. In this work, we have measured outcrop gamma-ray emission from the type section : gamma-ray peaks recognised on all datasets are used to attempt a correlation of the Lower Greensand Group between the Isle of Wight and an offshore borehole (99/16-1). This is partially successful, showing that Fitton and Casey's stratigraphy maybe recognised basin-wide.

${ }^{1}$ School of the Natural Built Environment, Queen's University, Belfast, BT7 1NN, UK

${ }^{2}$ Basin and Reservoir Laboratory, Department of Earth Sciences, Dalhousie University, Halifax NS, B3H 4R2, Canada

\section{Introduction}

Fitton (1847) and Casey (1961) detailed the Chale Bay (south-west coast, Isle of Wight) succession for stratigraphic account and the basis for Aptian-Albian biostratigraphy (respectively) on account of its completeness, albeit it represents a depositional system we now know is prone to hiatuses. The Aptian - Albian is important due to the discovery of Oceanic Anoxic Events, carbon, oxygen and strontium isotope excursions, global eustatic and palaeoclimate changes during this time The Chale Bay succession is not seen in much the same form anywhere else: equivalent strata exposed elsewhere on the Isle of Wight are dominated by less-fossiliferous, coarse-grained limonitic sands (Redcliff, parts of Compton Bay), or are protected from coastal erosion and thus weathered (Sandown Bay). The Atherfield Clay is recognised in the Weald Basin (including Perna Member [formerly Beds]); Sandrock facies are likewise known in the Folkestone Formation and at Swanage 
(Dorset) and in Albian successions in northern France (Pays de Caux between Etret and Le Havre: see Le Loeuff et al., 2013). The Ferruginous Sands Formation (sensu stricto) is largely restricted to the Isle of Wight. To those used to working in the epeiric seaway successions of the Upper Cretaceous (e.g. Chalk), the Upper Jurassic (e.g. Kimmeridge Clay), the Lower Jurassic (e.g. the Lias), or indeed the deep marine Lower Palaeozoic shales and greywackes of Scandinavia, British Isles and North America, commonly find marker beds (bentonites, tsunamites, marine bands) and facies that extend for tens to hundreds of kilometres, sometimes in different basins (Neuendorf et al., 2005). Only one or two 'beds' of the Lower Greensand Formation (Perna Member, base nutfieldiensis pebble beds, fuller's earths) can be compared for just tens of kilometres. That the early workers, followed by Casey, could barely identify the bulk of the Lower Greensand stratigraphy at neighbouring Sandown (Redcliff) or Compton Bay (Figure 1) proves this point: the Isle of Wight successions lay a few kilometres south of the contemporaneously-active Isle of Wight normal fault (to be inverted as a reverse fault - monocline) and in shallow marine conditions and were thus subject to rapid lateral facies and thickness changes. It is to the credit of the early workers like Fitton who identified at least some of the lowermost (Atherfield Clay Formation) and uppermost (late Aptian - early Albian Sandrock Formation) members and formations elsewhere on the Isle of Wight. The fossiliferous Upper Aptian nutfieldiensis Zone sediments of Shanklin were recognised as equivalents to the Chale Bay succession by Fitton (1847) and later workers (Table 1). More recently, parts of the Ferruginous Sands Formation have also been recognised at Compton Bay, Redcliff (Simpson, pers. comm, 2018). With oil exploration, and geophysical chemostratigraphy (gamma-ray logging), we here suggest that Fitton's (1847) lithostratigraphic divisions, on which Casey (1961) based his seminal ammonite zonation, can be recognised some 45-50 kilometres to the south-east, in Channel Basin borehole 99/16-1, drilled by Total Energy in 1982 (Figure 1), and maybe observable in other, adjacent boreholes.

\section{The Lower Greensand (Atherfield Clay and Ferruginous Sands) of the Channel Basin}

The Cretaceous succession of the Isle of Wight and specifically the type sections along the south coast (Figure 1) comprises (from the base) terrestrial (fluvial, palaeosols) Wessex Formation; lacustrinelagoonal Vectis Formation (both Wealden Group); marine Lower Greensand/Monks Bay Sandstone (formerly Carstone), Gault Clay, Upper Greensand and Chalk. This transgressive succession was deposited at the northern limit of the Channel Basin, south of the Isle of Wight High, which in the Neogene was inverted to become a monocline ((Gale et al., 1996). The Cretaceous of the Channel Basin is only exposed along this northern edge (Isle of Wight, Purbeck), the remainder of our knowledge of this succession coming from offshore seismic data and for this work, boreholes. The Lower Greensand of the Channel Basin is poorly-known, being thin and progressively unfossiliferous in the north of the Isle of Wight and on the Isle of Purbeck, hence borehole information is important. 
Fitton (1847) based his stratigraphy of the Lower Greensand on a combination of lithological changes and fossils: the divisions he recognised are separated by what we now recognise as hiatuses. Casey's (1961) work zone and sub-zone boundaries were based on ammonites, where changes in the fauna are often coincident with these breaks or changes in deposition. This makes the Chale Bay succession less suitable for seeking a complete biostratigraphic record for the Aptian but does allow us a good understanding of the correlation and processes of change in a shallow marine succession (Ruffell \& Wach, 1998). The problem here is believing that the essentially one-dimensional (vertical) stratigraphy of Chale Bay has any meaning laterally, beyond the remaining extensive but often inaccessible cliff exposures of Chale Bay and few horizons found elsewhere, mentioned above. In the sand-prone successions of the Ferruginous Sands, this is to be expected, and even in the argillaceous Atherfield Clay, it is the changes from Chale Clay, to Lobster Beds and Crackers that are coincident with Casey's ammonite zones. To find even the most prominent of lithostratigraphic changes within the Ferruginous Sands some tens of kilometres away then imparts significance to those particular surfaces. Without cored boreholes in the Channel Basin, only the broadest of lithostratigraphic comparisons can be attempted, hence we cannot detail Fitton's (1847) succession any further than the gamma-ray log motifs seen at outcrop and in borehole 99-16/1. The stratigraphic nomenclature used by) are summarised in Table 1.

\section{Gamma-ray Measurements from the Lower Greensand and Contiguous Deposits Above and}

\section{Below}

\subsection{Gamma-ray Measurement}

Potassium (K), uranium (U) and thorium (Th) comprise the bulk of the total natural gamma-ray count in rocks. The total count, and the isotopes of these three elements can be measured non-destructively and in real time, such as at outcrop or in a borehole, using a spectral gamma ray detector (Slatt et al., 1992). Phanerozoic sedimentary successions often show systematic changes in K, U and Th contents that appear to compare to other indicators of sea-level change, diagenesis and palaeoclimate change in the hinterlands. The sections measured here are dominated by kaolinite, smectite/mixed smectite-illite and illite, with subordinate chlorite. When successions with unusual clay minerals, heavy minerals, black shales or carbonate are measured, so the $\mathrm{K}$, $\mathrm{U}$ or Th distribution becomes difficult to interpret (Hurst, 1990; Ruffell \& Worden, 2000; van Buchem et al., 1992). K is common in many sediments that bear orthoclase and microcline feldspars $\left(\mathrm{KalSi}_{3} \mathrm{O}_{8}\right.$, muscovite mica $\left(\mathrm{H}_{2} \mathrm{KAl}\left(\mathrm{SiO}_{4}\right)_{3}\right.$ or clays. $\mathrm{U}$ and Th have a number of host minerals in sedimentary rocks including clays, heavy minerals, phosphates and organic matter. Whilst the various clay species have different sites for $U$ and $T h$, there is evidence to support some relationship between detrital kaolinite and $U$ or detrital illite with Th (Myers \& Bristow, 1989 and Slatt et al., 1992) as well as with different heavy minerals (Hurst, 1990). The main complication in this simplistic view is that Th and $\mathrm{U}$ are commonly found in inclusions within clays and micas and not as part of the crystal structure itself (Hurst, 1990). This relationship is 
not detectable without recourse to petrography. The $\mathrm{U}$ and Th content of sediments is undoubtedly also influenced by the presence of other minerals, especially those of the heavy mineral suite, as suggested by Myers \& Bristow (1989) and Hurst (1990). Regardless of these complications, log-motif analysis of gamma-rays is now standard practice in stratigraphic analysis for detection of sediment cycles/parasequences and identification of key boundaries such as flooding surfaces, both from outcrop and subsurface datasets (Nazeer et al., 2016).

\subsection{Gamma-ray Measurement from Boreholes and Outcrop}

Boreholes drilled for any purpose regularly have down-hole devices deployed to allow formation evaluation and correlation. This is especially true for hydrocarbon exploration, where finance and government laws promotes the need for as much information to be extracted from the drill-hole as possible. Many of the hydrocarbon boreholes drilled in, or offshore Southern England to 1990, relevant to assessing the nature of the Chale Bay succession have already been summarised in Ainsworth et al. (1998); Gale et al. (1996); Ruffell (1991), further records are publicly available via the British Geological Survey. Amongst these, a 120m thick succession of Lower Greensand was penetrated by borehole 99/16-1, drilled in the Channel Basin (Figure 1): thinner successions are recorded in neighbouring boreholes (99/12-1 and 99/18-1: see Gale et al., 1996 and Ruffell, 1991). This succession most likely (on thickness alone) may be comparable to the Chale Bay succession: a gamma-ray and sonic log of 99/16-1 was included in basin-wide borehole correlations in Ruffell (1991). The question is, without continuous core, and the issue of mixed rock cuttings brought to surface in drilling mud, how is this to be compared to outcrop. The running of a gamma-ray log in the offshore borehole can be compared to outcrop gamma-ray measurements. The borehole record is based on a cylindrical sonde, measuring surrounding rocks (more or less, excepting sloughing from the sidewall) and calibrated to an international standard (known as API, American Petroleum Institute) standards. The outcrop record is based on a hand-held device, with rock only to one side of the device. This work examines outcrop total count data derived using a Scintrex GIS-5 spectral gamma ray device and that published in Ruffell \& Worden (2000) using both a Geonics-256 and Scintrex GIS-5 to make spectral (total count, K, U and Th) measurements and comparison to the offshore borehole 99-16/1 (Figure 2) through the type section from Atherfield to Rocken End (Chale Bay: Figure 3). The absolute measurements of borehole and the outcrop detectors cannot be compared without mathematical adjustment: here it is not the measurements of natural radioactivity we are considering, it is the relative vertical changes, or log-motif analysis (sensu Nazeer et al., 2016). The outcrop devices are spectral (see Fig. 3), allowing differentiation of the K, $U$ and Th derived sources of gamma radiation. At the time of drilling, oil industry technology allowed only the downhole measurement of total gamma-ray emission, and thus it is this total count variation that is compared between the Chale Bay outcrop and the 99/16-1 subsurface. 


\section{Gamma-ray Logs from Chale Bay and Offshore Borehole 99/16-1}

The output from outcrop gamma-ray logging of the Chale Bay type section is shown in Figure 2. This was based on taking 52 measurements at $2-3 \mathrm{~m}$ (depending on exposure) vertical spacing. No such lithostratigraphic detail exists for the offshore borehole gamma-ray log from 99/16-1, so only a summary $\log$ for this succession is available, and the Chale Bay log is reduced in detail by averaging the gamma-count, to allow comparison (Figure 2). The detailed logs for individual parts of the outcrop succession are tabulated (below, Table 2). Offshore borehole 99/16-1 was drilled in 1982-3 by Total Energy to a total depth of 6075 feet (as reported) or $1851 \mathrm{~m}$ : the Jurassic - Wealden part of this borehole (with gamma-ray log) is shown in Ainsworth et al. (1998); the Lower and Upper Greensand and Gault succession (again with gamma-ray and sonic logs), is shown in Ruffell (1991).

\section{Discussion}

An increase in total gamma-ray emission at both outcrop and in borehole 99/16-1 are evident at the (1) top of the Perna Member, at the transition to the Atherfield Clay Formation, not at the base of the Perna Member, as would be expected for a flooding surface where clays and enhanced organic carbon provide thorium and uranium and increase the gamma-ray output. This work seeks to examine a correlation with the offshore gamma-ray curve, so spectral data of the individual K, U and Th contents is not considered: a spectral log through the Perna Member would (in future) assist in explaining this gamma-ray peak. Likewise, a peak (2) occurs at outcrop at the top of the Upper Lobster Member (at its transition to the Ferruginous Sands Formation: base of Member IV Lower Gryphaea) which would be expected to show a decrease in gamma-ray output. A third peak (3i) is seen at outcrop at the top of Member VI Scaphites, which is a condensed section (Ruffell \& Wach, 1988). The high gamma-count continues after a sharp fall into Member VI Lower Crioceras (at outcrop and in boreholes) and in Member VII (3ii) forms the most distinctive gamma ray peak in all datasets. No elevated gamma-ray counts occur at the base of XIII Walpen in both borehole 99/16-1 and at outcrop, but a number of spikes (4) occur in Member XIV Blackgang Chine: this being representative of the cunningtoni subzone of the nutfieldiensis transgression, seen globally (Wach \& Ruffell, 1990). Peaks also occur (5) in the dark, laminated facies of the Sandrock (Figures 2 and 3) and in the Carstone/base of the Gault Formation (6), also as expected, this likewise being representative of a basin-wide transgression. Peaks 1, 3, 4 and 6 occur at flooding surfaces previously identified from sequence stratigraphy (Ruffell \& Wach, 1998). The overall pattern of gamma-ray emission from the Lower Greensand Group from this work, and in borehole 99/16-1 are comparable to that shown in Figure 3 (after Ruffell \& Worden, 2000), derived using an older gamma-ray detector. These show comparisons to the $\delta 13 \mathrm{C}$ (WOOD) data obtained by Grocke et al., (1999), who showed a link to palaeoclimate, thus suggesting that the gamma-log reflects not just sea-level change, but broader shifts in the overall palaeoenvironment. This complication may explain why some gamma-ray peaks conform to previously-recognised transgressive surfaces. What is surprising is that no gammaray peak occurs at the base of the Perna Member, or at the pebble-bed base of Member XIII Walpen: the condensed nature of Member XIV Blackgang Chine may represent the peak of the nutfieldiensis transgression. Whatever the causes of stratigraphic shifts in gamma-ray output from sedimentary rocks, the correlation of such gamma-ray changes (onshore and offshore) to Fitton (1847) and Casey's (1961) litho- and biostratigraphy, shows that these two legendary workers had an eye for the succession and it's fauna we have vindicated through use of geophysics.

\section{Acknowledgements}


We are deeply indebted to Martin Simpson, without who the stratigraphy of the Lower Greensand of the Isle of Wight would remain a mystery. Original borehole composite log was supplied by the Department of Trade and Industry.

\section{References}

Ainsworth, N.R., Braham, W., Gregory, F.J., Johnson, B., King, C. 1998. A proposed latest Triassic to earliest Cretaceous microfossil biozonation for the English Channel and its adjacent areas. In: Underhill, J.R. (ed.), Development, Evolution and Petroleum Geology of the Wessex Basin. Geological Society, London, Special Publication 133, 87-102.

Casey, R. 1961. The stratigraphical palaeontology of the Lower Greensand. Palaeontology, 3, 487621.

Bristow, H.W. 1889. Geology of the Isle of Wight. Memoirs of the Geological Survey of Great Britain.

Fitton, 1847. A stratigraphical account of the section from Atherfield to Rocken-end on the southwest coast of the Isle of Wight. Quarterly Journal of the Geological Society, London, 3, 289-327.

Gale, A.S., Huggett, J.M., Gill, M. 1996. The stratigraphy and petrography of the Gault Clay Formation (Albian, Cretaceous) at Redcliff, Isle of Wight. Proceedings of the Geologists' Association, 106, 287-298.

Grocke, D., Hesselbo, S.P., Jenkyns, H.C., 1999. Carbon-isotope stratigraphy of Lower Cretaceous fossil wood: ocean-atmosphere chemistry and relation to sea-level change. Geology, 27, 155-158.

Hurst, A. 1990 Natural gamma ray spectrometry in hydrocarbon-bearing sandstones from the Norwegian continental shelf. In: A. Hurst, M. Lovell and A. Morton (Editors) Geological Applications of Wireline Logs. Geology Society London Special Publication, 48, p.211-222.

Le Loeuff, J., Suteethorn, S. \& Buffetaut, E. 2013. Anew sauropod dinosaur from the Albian of Le Harve (Normandy, France). Oryctos, 10, 24-32.

Myers, K.J., Bristow, C.S. 1989 Detailed sedimentology and gamma ray log characteristics of a Namurian deltaic succession II: Gamma ray logging. In: M.K.G. Whateley and K.T. Pickering (Editors) Deltas: Sites and Traps for Fossil Fuels. Geological Society Special Publication 41, 8188.

Nazeer, N, Abbasi, S.A. \& Solangi, S.H. 2016. Sedimentary facies interpretation of Gamma Ray (GR) $\log$ as basic well logs in Central and Lower Indus Basin of Pakistan. Geodesy and Geodynamics, 7, 432-443.

Neuendorf, K.K.E, Mehl, J.P. \& Jackson, J.A. 2005. Glossary of Geology (5 $5^{\text {th }}$ Edition). American Geological Institute, Alexandria, Virginia, USA. 779pp.

Ruffell, A.H. 1991. Geophysical correlation of the Aptian and Albian formations in the Wessex Basin of southern England. Geological Magazine, 128, 67-75.

Ruffell, A., Wach, G. 1998. Firmgrounds - key surfaces in the recognition of parasequences in the Aptian Lower Greensand Group, Isle of Wight (southern England). Sedimentology, 45, 91-107.

Ruffell, A.H., Worden, R.H. 2000 Palaeoclimate analysis using spectral gamma ray data from the Aptian (Cretaceous) of southern England and southern France. Palaeoecology, Palaeogeography, Palaeoclimatology 154, 313 - 325

Slatt, R.M., Jordan, D.W., D'Agostino, A., Gillespie, R.H. 1992 Outcrop gamma ray logging to improve understanding of subsurface well log correlations. In: Hurst, A., Griffiths, C.M. and Worthington, F. (Editors) Geological Applications of Wireline Logs II. Geological Society Special Publication 65 3-19.

Simpson, M.I. 1985. The stratigraphy of the Atherfield Clay Formation (Lower Aptian, Lower Cretaceous) the type locality and other localities in southern England. Proceedings of the Geologists' Association, 96, 23-45. 
van Buchem, F.S.P., Melynk, D.H., McCave, I. 1992 Chemical cyclicity and correlation of Lower Lias mudstones using gamma ray logs, Yorkshire, UK. Journal of the Geological Society, London, 149, 991 $-1002$.

Wach, G.D., Ruffell, A.H. 1991. Sedimentology and Sequence Stratigraphy of a Lower Cretaceous Tideand Storm-dominated clastic succession, Isle of Wight and S.E. England. Cambridge University, British Sedimentological Research Group, Field Guide 4, 100pp.

Figure Captions

Figure 1. Location of the study area in the British Isles, the Weald and Channel basins (including borehole 99/16-1) and Isle of Wight.

Figure 2. Comparison of outcrop gamma-ray measurements (this work) with offshore borehole 99/161 (from Department of Energy records and in Ruffell, 1991). The Lower Greensand in this borehole was identified from borehole cuttings by Total Energy. Bracketed numbers refer to the gamma-ray peaks discussed in text; Roman numerals refer to the divisions of Fitton (1847) that can be confidently correlated by gamma-ray motif to the Chale Bay type section.

Figure 3. Comparison of clay mineral analyses, carbon isotopes (after Grocke et al. 1999) and spectral gamma-ray measurements. Reproduced from Ruffell \& Worden (2000), with modifications (e.g. numbered gamma-ray peaks referred to in text). Note that the broad gamma-ray motif is similar to that shown in Figure 2, with some variations caused by different devices being used and the location of each gamma-ray reading.

Table 1. The stratigraphic divisions of Fitton (1847), The Geological Survey of England and Wales (1889), Casey (1961), Simpson (1985) and Ruffell \& Wach (1998).

Table 2. List of detailed field gamma-ray logs available as supplementary material.

\begin{tabular}{|l|}
\hline 8. Sandrock Formation, Rocken End \\
\hline 7. Horse Ledge, Shanklin \\
\hline 6. Member IV Lower Crioceras \\
\hline 5. Member IV Lower Gryphaea and Member V Scaphites \\
\hline 4. Member IV Lower Gryphaea \\
\hline 3. Barnes High Sandstone correlation \\
\hline 2. Barnes High Sandstone, Cowleaze Chine - Shippards Chine \\
\hline 1. Vectis Formation, Chale Bay \\
\hline
\end{tabular}

